\title{
PENGARUH EARNING PER SHARE, DIVIDEND PER SHARE DAN FINANCIAL LEVERAGE TERHADAP HARGA SAHAM PADA PERUSAHAAN FOOD AND BEVERAGE YANG TERDAFTAR DI BURSA EFEK INDONESIA
}

\author{
Mortigor Afrizal Purba \\ Dosen Universitas Putera Batam \\ email: mortigor@puterabatam.ac.id
}

\begin{abstract}
The stock price describes the performance of the company. The better the performance of the company, the higher the stock price. Therefore the company needs to maintain the company's performance so that the stock price does not decline continuously every year. One way to find out that the company has good corporate performance by comparing the company's financial ratios from the previous year to the following year.

The aim of this study is to examine the effect of EPS, DPS, and Financial Leverage on the stock prices of food and beverage companies listed on the Indonesia Stock Exchange 20142018. The population in this study amounted to 18 food and beverage companies with the period 2014-2018. While the sample selected using the purposive sampling method with a total of 9 companies for 5 years processed data as many as 45 data.

Data tested using basic assumptions, classic assumption tests, multiple linear regression tests and hypothesis testing. The results of the study show that EPS, DPS, and Financial Leverage simultaneously have a significant effect on stock prices. While partially EPS has a significant effect on stock prices, DPS has no significant effect on stock prices, and Financial Leverage also does not have a significant effect on stock prices.
\end{abstract}

Keywords: EPS, DPS, Financial Leverage, Stock Price

\section{PENDAHULUAN}

Ketatnya persaingan dalam dunia bisnis menjadi pemicu yang kuat bagi setiap perusahaan untuk menampilkan performa terbaik, karna baik buruknya performa perusahaan akan berdampak pada nilai pasar dan mempengaruhi minat investor untuk menanam atau menarik investasinya dari sebuah perusahaan. Perusahaan membutuhkan investor untuk menanamkan investasi yang diperlukan utuk menjaga kelangsungan perusahaan. Salah satu tmpat untuk memperoleh dana dari investor tersebut adalah melalui pasar modal.

Pada dasarnya harga saham terbentuk dari interaksi antara penjual dan pembeli yang terjadi di bursa efek yang akan bergerak sesuai dengan kekuatan permintaan dan penawaran yang terjadi atas saham tersebut. Sehingga semakin banyak investor yang meminati saham perusahaan makanan dan minuman maka semakin tinggi pula harga saham yang ditawarkan. Hal ini dapat dilihat dari indeks harga saham kelompok makanan dan minuman yang merupakan salah satu dari 5 indeks sektoral di Bursa Efek Indonesia yang mempunyai tingkat harga saham yang cukup baik selain industri pertanian, pertambangan, industri dasar dan kimia, dan aneka industri.

Dengan adanya peningkatan rata-rata jumlah penduduk sekitar 4 juta per tahun, akan menjadi penyumbang utama pertumbuhan industri makanan dan minuman. Industri makanan dan minuman diprediksi tumbuh $8 \%-9 \%$ pada 2019, relatif stagnan dengan target tahun ini. Pertumbuhan industri tersebut diharapkan sejalan peningkatan jumlah populasi penduduk dan pertumbuhan ekonomi( GAPMMI). Peningkatan rata-rata jumlah penduduk sekitar 4 juta per tahun, akan menjadi penyumbang utama pertumbuhan. Sementara agenda politik 2019 tak 
terlalu besar mengerek konsumsi makanan minuman. "Tahun politik tentu ada dampaknya buat peningkatan konsumsi, tapi tak signifikan," kata Adhi kepada Katadata.co.id.

Karena alasan tersebut, maka para investor yang akan berinvestasi di pasar modal memerlukan pertimbangan yang sangat matang dan informasi yang akurat agar investasi yang dilakukan tidak terjebak dalam kondisi yang merugikan. Hal tersebut perlu diperhatikan mengingat investasi di pasar modal merupakan suatu jenis investasi yang memiliki resiko yang relatif tinggi dengan keuntungan yang relatif tinggi pula. Oleh karena itu, dalam menanamkan modalnya di suatu perusahaan, investor terlebih dahulu harus mendapatkan informasi yang lengkap dan akurat tentang kinerja suatu perusahaan. Investor harus dapat menganalisis perusahaan berdasarkan analisis teknikal dan analisis fundamental. Investor harus mampu menganalisis suatu perusahaan berdasarkan analisis fundamental dalam menilai kinerja keuangan suatu perusahaan.

Analisis fundamental tersebut bisa dilakukan dengan menganalisis berbagai rasio keuangan yang ditampilkan dalam laporan keuangan perusahaan. Rasio-rasio keuangan tersebut sangatlah penting untuk menilai kinerja keuangan atau prestasi perusahaan yang juga akan berdampak pada kemudahan penilaian investor terhadap harga saham perusahaan seperti earning per share, dividend per share dan financial leverage menjadi kebutuhan yang sangat mendasar dalam kebutuhan pengambilan keputusan. Informasi tersebut dapat mengurangi ketidakpastian dan resiko yang mungkin terjadi karena seperti yang diketahui bahwa earning per share, dividend per share, serta financial leverage sangat erat kaitannya dengan profitabilitas perusahaan dimana profitabilitas adalah suatu factor yang sangat berpengaruh terhadap penilaian harga saham oleh para Investor sehingga keputusan yang diambil diharapkan akan sesuai dengan tujuan yang diinginkan.

Selain itu ada permasalahan yang dihadapi oleh investor dipasar modal adalah adanya kesulitan untuk menentukan keputusan investasinya dan faktor apa yang menentukan harga saham di Bursa Efek. Selain itu profitabilitas yang tinggi adalah hal yang selalu didambakan oleh perusahaan pada umumnya, kesejahteraan pemegang saham akan terpenuhi jika perusahaan mendapatakan laba yang besar, komponen posisi keuangan suatu perusahaan terdiri dari aktiva, hutang, dan modal. Pembelian aktiva dapat dilakukan secara tunai maupun secara kredit sehingga menimbulkan hutang. Modal awal perusahaan selalu terdiri dua komponen modal sendiri dan modal pinjaman, perusahaan tidak bias terlepas dari hutang. Hutang sendri terbagi menjadi dua katagori yaitu hutang jangka panjang dan hutang jangka pendek.

\section{Rumusan Masalah}

Berdasarkan latar belakang yang telah dikemukakan sebelumnya, maka rumusan masalah penelitian ini adalah sebagai berikut:

1. Apakah Earning per share mempunyai pengaruh positif dan signifikan terhadap perubahan harga saham Perusahaan food and beverage di Bursa Efek.

2. Apakah Dividend per share mempunyai pengaruh positif dan signifikan terhadap perubahan harga saham Perusahaan food and beverage di Bursa Efek.

3. Apakah Financial Leverage mempunyai pengaruh positif dan signifikan terhadap perubahan harga saham Perusahaan Food and Beverage di Bursa Efek.

4. Apakah Earning Per Share, Dividend Per Share dan Financial Leverage secara simultan mempunyai pengaruh positif dan signifikan terhadap perubahan harga saham Perusahaan Food and Beverage di Bursa Efek

\section{TINJAUAN PUSTAKA}

\section{Faktor-faktor yang Mempengaruhi Harga Saham}

Harga saham yang terjadi di pasar modal selalu berfluktuasi dari waktu ke waktu. Fluktuasi harga saham tersebut akan ditentukan oleh kekuatan penawaran dan permintaan. Jika jumlah penawaran lebih besar dari jumlah permintaan, pada umumnya kurs harga saham akan turun. Sebaliknya jika jumlah permintaan lebih besar dari jumlah penawaran terhadap suatu efek maka harga saham cenderung akan naik. Faktor-faktor yang mempengaruhi fluktuasi harga 
saham dapat berasal dari internal dan eksternal perusahaan. Menurut Alwi (2003:87), faktorfaktor yang mempengaruhi pergerakan harga saham yaitu:

1) Faktor Internal yaitu:

a. Pengumuman tentang pemasaran, produksi, penjualan seperti pengiklanan, rincian kontrak, perubahan harga, penarikan produk baru, laporan produksi, laporan keamanan produk, dan laporan penjualan.

b. Pengumuman pendanaan (financing announcements), seperti pengumuman yang berhubungan dengan ekuitas dan hutang.

c. Pengumuman badan direksi manajemen (management board of director announcements) seperti perubahan dan pergantian direktur, manajemen, dan struktur organisasi.

d. Pengumuman pengambilalihan diversifikasi, seperti laporan merger, investasi ekuitas, laporan take over oleh pengakuisisian dan diakuisisi.

e. Pengumuman investasi (investment announcements), seperti melakukan ekspansi pabrik, pengembangan riset dan penutupan usaha lainnya.

f. Pengumuman ketenagakerjaan (labour announcements), seperti negoisasi baru, kontrak baru, pemogokan dan lainnya.

g. Pengumuman laporan keuangan perusahaan, seperti peramalan laba sebelum akhir tahun fiskal dan setelah akhir tahun fiskal, earning per share (EPS), dividen per share (DPS), price earning ratio, net profit margin, return on assets (ROA), dan lain-lain.

2 Faktor Eksternal yaitu:

a. Pengumuman dari pemerintah seperti perubahan suku bunga tabungan dan deposito, kurs valuta asing, inflasi, serta berbagai regulasi dan deregulasi ekonomi yang dikeluarkan oleh pemerintah.

b. Pengumuman hukum (legal announcements), seperti tuntutan karyawan terhadap perusahaan atau terhadap manajernya dan tuntutan perusahaan terhadap manajernya.

c. Pengumuman industri sekuritas (securities announcements), seperti laporan pertemuan tahunan, insider trading, volume atau harga saham perdagangan, pembatasan/penundaaan trading.

d. Gejolak politik dalam negeri dan fluktuasi nilai tukar juga merupakan faktor yang berpengaruh signifikan pada terjadinya pergerakan harga saham di bursa efek suatu negara.

e. Berbagai isu baik dari dalam dan luar negeri

\section{Earning per Share}

Menurut Fabozzi (2011:861), "earning per share adalah perbandingan antara laba yang tersedia bagi pemegang saham biasa (laba setelah pajak dikurangi dividen saham preferen) dengan jumlah saham yang beredar selama periode perhitungan yang dilakukan". Dengan demikian, earning per share merupakan besaran pendapatan yang diterima oleh para pemegang saham dari setiap lembar saham biasa yang beredar dalam periode waktu tertentu.

Menurut Tandelilin (2010:373), "earning per share adalah laba bersih setelah bunga dan pajak yang siap dibagikan kepada pemegang saham dibagi dengan jumlah lembar saham perusahaan". Menurut Baridwan (2009:443), "laba bersih per saham adalah jumlah pendapatan yang diperoleh dalam satu periode untuk tiap lembar saham yang beredar, dan akan dipakai oleh pimpinan perusahaan untuk menentukan besarnya dividen yang akan dibagikan".

Tujuan perhitungan earning per share menurut Machfoedz (2010:356), adalah "untuk melihat kemajuan (progress) dari operasi perusahaan, menentukan harga saham, dan menentukan besarnya dividen yang akan dibagikan". Selanjutnya Syamsudin (2009:66) mengatakan bahwa "pada umumnya para pemegang saham tertarik dengan earning per share (EPS) yang besar karena hal tersebut merupakan salah satu indikator keberhasilan perusahaan".

Salah satu alasan investor membeli saham adalah untuk mendapatkan deviden, jika nilai earning per share kecil, maka kecil pula kemungkinan perusahaan untuk membagikan deviden. Maka dapat dikatakan investor akan lebih meminati saham yang memiliki earnings per share tinggi dibandingkan saham yang memiliki earnings per share rendah. Earnings per share yang rendah cenderung membuat harga saham turun. 


\section{Dividend per Share}

Investasi dalam bentuk saham akan memberikan keuntungan kepada investor, yaitu keuntungan berupa dividen dan capital gain. Capital gain diperoleh dari selisih harga jual dan beli saham. Sedangkan menurut Tangkilisan dan Hessel (2008:227), "dividen adalah bagian dari laba bersih yang dibagikan kepada para pemegang saham". Stice (2009:902) menyatakan bahwa "dividen adalah pembagian keuntungan kepada pemegang saham dari suatu perusahaan secara proporsional sesuai dengan jumlah lembar saham yang dipegang oleh masing-masing pemilik".

Sehingga dari pengertian diatas dapat disimpulkan bahwa dividen adalah bagian keuntungan bersih setelah pajak yang dibagikan kepada pemegang saham. Dividen merupakan salah satu potensi keuntungan dari investasi melalui saham, maka pihak manajemen perusahaan perlu memperhatikan kebijakan dividen yang akan diterapkan dalam rangka menarik minat investor untuk menanamkan modalnya dalam perusahaan dalam bentuk kepemilikan saham.

Dividend per share merupakan rasio yang mengukur seberapa besar dividen yang dibagikan dibandingkan dengan jumlah saham yang beredar pada tahun tertentu. Rasio ini memberikan gambaran mengenai seberapa besar laba yang dibagikan dalam bentuk dividen kepada pemegang saham untuk tiap lembar saham. Rasio ini dihitung dengan membagi jumlah dividen yang dibayarkan dengan jumlah saham yang beredar.

\section{Financial Leverage}

Financial leverage dapat diartikan sebagai kemampuan perusahaan dalam menggunakan kewajiban-kewajiban keuangan yang sifatnya tetap untuk memperbesar pengaruh perubahan Earning Before Interest and Taxes terhadap pendapatan per lembar saham biasa (Earning Per Share). Financial leverage timbul karena adanya kewajiban-kewajiban keuangan yang sifatnya tetap yang harus di bayar oleh perusahaan yaitu bunga atas hutang dan dividen untuk saham preferen. Penggunaan financial leverage dalam struktur modal perusahaan dengan harapan agar terjadi perubahan laba per lembar saham (Earning Per Share) yang lebih besar daripada perubahan laba sebelum bunga dan pajak (Earning Before Interest and Taxes).

Multiplier effect yang dihasilkan karena penggunaan dana dengan biaya tetap ini disebut dengan tingkat leverage keuangan (Degree of Financial Leverage). Degree of financial leverage mengukur perubahan Earning Per Share karena perubahan Earning Before Interest and Taxes atau rasio antara persentase perubahan Earning Per Share dibanding dengan persentase perubahan Earning Before Interest and Taxes (Sartono, 2010:265).

\section{Kerangka Berpikir}

Berdasarkan uraian-uraian sebelumnya terdapat variabel yang dapat diidentifikasi mempengaruhi variabel independen Earning per Share (EPS), Dividend per Share (DPS) dan Financial Leverage, Variabel dependen dalam penelitian ini adalah harga saham. Sehingga kerangka pemikiran penelitian ini dapat digambarkan sebagai berikut:

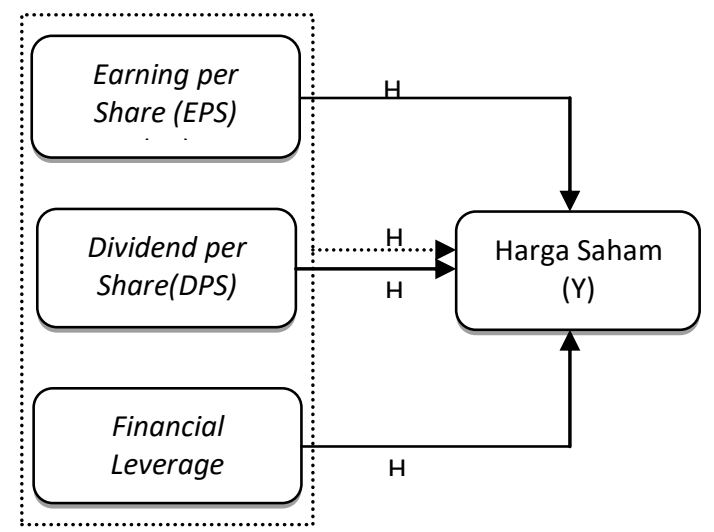

Gambar 1. Kerangka Berpikir 


\section{METODE}

\section{Desain Penelitian}

Desain penelitian merupakan tahapan atau gambaran mengenai berbagai komponen yang akan digunakan peneliti serta kegiatan yang dilakukan selama proses penelitian. Proses ini merupakan tahap awal dalam proses penelitian. Dalam penelitian ini, penulis melakukan beberapa tahapan-tahapan yang saling berkaitan dan merangkai proses penelitian. Penyusunan desain penelitian ini dilakukan agar penelitian dapat berjalan dengan baik dan sistematis. Desain penelitian ini berguna bagi semua pihak yang terlibat dalam proses penelitian.

Populasi dan Sampel

Teknik pengambilan sampel dalam penelitian ini mengunkan purposive sampling metho menurut (Sugiyono, 2014:85) yaitu teknik penentuan sampel dengan pertimbangan tertentu. Sample diperoleh dari perusahaan - perusahaan Food \& Beverage yang terdaftar di Bursa Efek Indonesia dengan kriteria sebagai berikut:

1. Perusahan yang bergerak di bidang Food \& Beverage yang terdaftar di Bursa Efek Indonesia.

2. Perusahaan yang bergerak di bidang Food \& Beverage tersebut telah melaporkan laporan keuangan untuk tahun 2014-2018.

3. Harga saham yang digunakan adalah harga saham yang berkisar antara Rp. 300 sampai Rp. 10.000 .

Berdasarkan kriteria sampel maka penelitian ini akan melakukan pemilihan sampel sebagai berikut:

Tabel 1. Sampel Perusahaan Food \& Beverage

\begin{tabular}{ccc}
\hline No & $\begin{array}{c}\text { Kode } \\
\text { Perusahaan }\end{array}$ & Nama Perusahaan \\
\hline 1 & CEKA & PT. Wilmar Cahaya Indonesia Tbk (d.h Cahaya Kalbar \\
& Tbk) \\
2 & DLTA & PT. Delta Djakarta Tbk \\
3 & ICBP & PT. Indofood CBP Sukses Makmur Tbk \\
4 & MYOR & PT. Mayora Indah Tbk \\
5 & ROTI & PT. Nippon Indosari Corporindo Tbk \\
6 & SKBM & PT. Sekar Bumi Tbk \\
7 & SKLT & PT. Sekar Laut Tbk \\
8 & PTTP & PT. Siantar Top Tbk \\
9 & ULTJ & PT. Ultrajaya Milk Industry and Trading Company Tbk \\
\hline
\end{tabular}

Sumber: Bursa Efek Indonesia (BEI), 2019

\section{Teknik Pengumpulan Data}

Jenis data yang digunakan dalam penelitian ini merupakan data kuantitatif (Sugiyono, 2014:7) yaitu dalam dalam bentuk kuantitas yang diwakili dengan mengunakan angka atau numeric dan analisis mengunakan statistik. Sumber data diperoleh dari ringkasan kinerja atau laporan keuangan perusahaan Food \& Beverage yang dipublikasi di Bursa Efek Indonesia yang telah diaudit dengan periode penelitian tahun 2014-2018. Data diperoleh dari situs resmi yaitu htpp://www.idx.co.id.

Teknik pengumpulan data yang digunakan dalam penelitian ini adalah teknik dokumentasi yaitu pengumpulan data dengan cara mengumpulkan data sekunder dari ringkasan kinerja atau laporan keuangan yang telah dipulikasikan di Bursa Efek Indonesia.

\section{HASIL DAN PEMBAHASAN}

\section{Analisis Deskriptif}

Analisis deskriptif mengambarkan bagaimanan hubungan pengaruh variabel independen terhadap variabel dependen. Data yang digunakan dalam penelitian ini merupakan data sekunder. Berdasarkan data yang diperoleh dari Bursa Efek Indonesia diketahui bahwa terdapat 
10 perusahaan yang bergabung dalam perusahaan Farmasi dan diperoleh sampel sebanyak 5 perusahan dengan jumlah data 30 yang telah di audit atau sesuai kriteria penelitan.

Tabel 2. Hasil Uji Statistik Deskriptif

Descriptive Statistics

\begin{tabular}{lrrr}
\hline & \multicolumn{1}{c}{ Mean } & Std. Deviation & $\mathrm{N}$ \\
\hline Harga Saham & 4286,9333 & 5931,28848 & 45 \\
EPS & 205,4860 & 246,33085 & 45 \\
DPS & 107,2444 & 163,42722 & 45 \\
Financial Leverage & 4,3022 & 11,74355 & 45 \\
\hline Sumber: Pengolahan
\end{tabular}

Sumber: Pengolahan dengan SPSS 2019

Berdasarkan tabel 4.2 di atas terdapat tiga variabel independen yaitu Harga Saham, EPS dan DPS sedangkan variabel dependen adalah Harga Saham dengan menunjukkan bahwa N (jumlah data) merupakan jumlah data yang valid yaitu sebanyak 45 data, variabel EPS memiliki rata-rata sebesar 205,49 dengan standart deviation (simpangan baku) 246,33, variabel DPS memiliki nilai rata-rata 107,24 serta standart deviation 163,43, variabel Fiancial Leverage memiliki nilai rata-rata 4,30 dan standart deviation 11,74 . Nilai rata-rata untuk variabel harga saham sebesar 4286,93 dan memiliki standart deviation 5931,29.

Uji Normalitas

Uji normalitas dikatakan berdistribusi nomal atau tidak dapat dilihat dari histogram regression residual, grafik p-p plot regression standardized residual dan uji KolmogorovSminov.

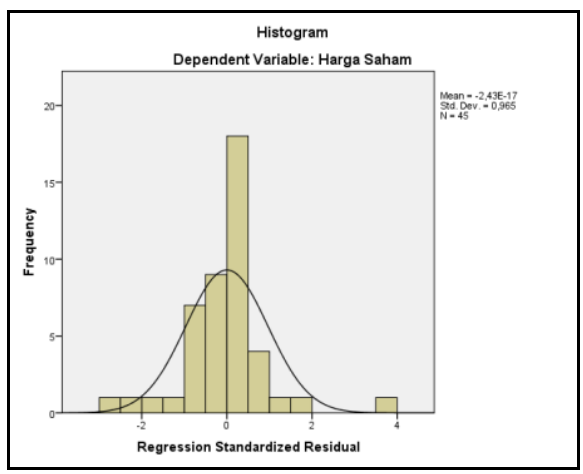

Gambar 2. Hasil Uji Normalitas - Histogram Regression Residual

\section{Hasil Uji Multikolinearitas}

Variabel yang menyebakan terjadinya multikolinearitas dapat dilihat dari nilai tolerance lebih besar dari 0,10 dan nilai VIF lebih kecil dari 10. Dari output regresi dikatakan nilai tolerance lebih besar dari 0,10 dan nilai VIF kurang dari 10 maka menunjukkan tidak terjadi multikolimearitas.

Tabel 3. Hasil Uji Multikolinearitas

\begin{tabular}{|c|c|c|c|}
\hline \multicolumn{4}{|c|}{ Coefficients $^{\mathbf{a}}$} \\
\hline \multirow[b]{2}{*}{ Model } & & \multicolumn{2}{|c|}{ Collinearity Statistics } \\
\hline & & Tolerance & VIF \\
\hline 1 & (Constant) & & \\
\hline & EPS & ,872 & 1,147 \\
\hline & DPS &, 872 & 1,147 \\
\hline & Financial Leverage & ,999 & 1,001 \\
\hline
\end{tabular}

Sumber: Pengolahan SPSS (2019)

Berdasarkan tabel 4.4 dimana nilai variabel EPS memiliki nilai tolerance 0,872>0,10 dan nilai VIF sebesar $1,147<10$, variabel $D P S$ memiliki nilai tolerance $0,872>0,10$ dan nilai 
VIF sebesar 1,147 < 10 dan variabel Fiancial Leverage memiliki nilai tolerance 0,999>0,10 dan niali VIF sebesar 1,001 < 10. Sehingga dalam hasil penelitian ini ditarik kesimpulan bahwa ketiga variabel independen EPS, DPS dan Fiancial Leverage tidak mengalami gejala multikolinearitas.

\section{Uji Koefisien Determinasi}

Analisis $\mathrm{R}^{2}$ atau koefisien determinasi digunakan untuk mengetahui seberapa besar presentase dengan menggunakan Adjusted $R$ Square biasanya untuk mengukur sumbangan pengaruh jika dalam regresi menggunakan lebih dari dua variable independen

Tabel 4. Hasil Uji Koefisiensi Determinasi

Model Summary

\begin{tabular}{lcccc}
\hline Model & R & R Square & $\begin{array}{c}\text { Adjusted R } \\
\text { Square }\end{array}$ & $\begin{array}{c}\text { Std. Error of } \\
\text { the Estimate }\end{array}$ \\
\hline 1 &, $890^{\mathrm{a}}$ &, 791 &, 776 & 2807,21388 \\
a. Predictors: (Constant), Financial Leverage, EPS, DPS
\end{tabular}

Sumber: Pengolahan SPSS (2019)

Hasil pengolahan Statistik uji $\mathrm{R}^{2}$ menunjukkan Adjusted $R$ Square sebesar 0,776 yang berarti kemampuan variabel independen dalam mempengaruhi variabel dependen sebesar $77,6 \%$ dan sisanya $22,4 \%$ dijelaskan oleh variabel lain yang tidak diteliti dalam penelitan ini.

\section{Hasil Uji Signifikansi Parsial (Uji Statistik t)}

Tujuan dilakukan uji signifikansi secara parsial dua variabel bebas (independen) terhadap variabel tak bebas (dependen) adalah untuk mengukur secara terpisah dampak yang ditimbulkan dari masing-masing variabel bebas (independen) terhadap variabel tak bebas (dependen) (Siregar, 2014:410) (Pengujian menggunakan tingkat signifikansi 0,05 dan 2 sisi).

Kriteria pengujian adalah jika $\mathrm{t}$ tabel $\leq \mathrm{t}$ hitung $\leq \mathrm{t}$ tabel, maka $\mathrm{H}_{\mathrm{O}}$ diterima dan jika $\mathrm{t}-$ hitung dan jika t-hitung $<\mathrm{t}$ tabel atau $\mathrm{t}$ hitung $>\mathrm{t}$ tabel, maka $\mathrm{H}_{\mathrm{O}}$ ditolak, kriteria untuk menentukan nilai t tabel dalam tabel statistik dengan taraf signifikansi 0,05 dengan derajat kebebasan df=n-k-1.

Tabel 5. Hasil Uji t

Coefficients $^{\mathrm{a}}$

\begin{tabular}{|c|c|c|c|c|c|c|}
\hline \multirow{2}{*}{\multicolumn{2}{|c|}{ Model }} & \multicolumn{2}{|c|}{$\begin{array}{c}\text { Unstandardized } \\
\text { Coefficients }\end{array}$} & \multirow{2}{*}{$\begin{array}{c}\text { Standardized } \\
\text { Coefficients } \\
\text { Beta }\end{array}$} & \multirow[b]{2}{*}{$\mathrm{t}$} & \multirow[b]{2}{*}{ Sig. } \\
\hline & & B & Std. Error & & & \\
\hline \multirow[t]{4}{*}{1} & (Constant) & $-399,424$ & 595,669 & &,- 671 & ,506 \\
\hline & EPS & 21,093 & 1,840 & ,876 & 11,464 & ,000 \\
\hline & DPS & ,939 & 2,773 & ,026 & ,339 & ,737 \\
\hline & $\begin{array}{l}\text { Financial } \\
\text { Leverage }\end{array}$ & 58,394 & 36,063 & ,116 & 1,619 & ,113 \\
\hline & endent Var & ga Saham & & & & \\
\hline
\end{tabular}

Sumber: Pengolahan SPSS (2019)

Berdasarkan tabel 4.8 hasil pengujian variabel bebas EPS, DPS dan Financial Leverage dapat disimpulkan bahwa:

1. Variabel EPS ditunjukkan dengan nilai $\mathrm{t}$ hitung 11,464 < $\mathrm{t}_{\text {tabel }} 2,0555$ (t tabel 2 sisi dengan df 45-3-1) dan nilai signifikansi memiliki nilai signifikansi sebesar 0,000< 0,05. Sehingga dapat disimpulkan bahwa $\mathrm{H} 1$ diterima, yang berarti bahwa EPS berpengaruh positif dan signifikan terhadap harga saham. Maka hipotesis pertama diterima.

2. Variabel DPS ditunjukkan dengan nilai $\mathrm{t}$ hitung $0,339<\mathrm{t}_{\text {tabel }} 2,0555$ ( $\mathrm{t}$ tabel 2 sisi dengan df 45-3-1) dan nilai signifikansi memiliki nilai signifikansi sebesar 0,737 > 
3. 0,05. Sehingga dapat disimpulkan bahwa H1 ditolak, yang berarti bahwa DPS berpengaruh positif dan tidak signifikan terhadap harga saham. Maka hipotesis kedua ditolak.

4. Variabel Financial Leverage ditunjukkan dengan nilai $\mathrm{t}_{\text {hitung }} 1,619<\mathrm{t}$ tabel $2,0555(\mathrm{t}$ tabel 2 sisi dengan df 45-3-1) dan nilai signifikansi memiliki nilai signifikansi sebesar $0,113>0,05$. Sehingga dapat disimpulkan bahwa $\mathrm{H} 3$ ditolak, yang berarti bahwa Financial Leverage berpengaruh positif dan tidak signifikan terhadap harga saham. Maka hipotesis ketiga ditolak.

\section{Uji Signifikansi Simultan (Uji Statistik F)}

Uji $\mathrm{F}$ atau koefisien regresi digunakan menguji signifikansi pengaruh beberapa variabel independen terhadap variabel dependen. Pengujian ini menggunakan tingkat signifikansi lebih kecil dari 0,05

\section{Tabel 6. Hasil Uji F}

\begin{tabular}{llrrrrr}
\multicolumn{8}{c}{ ANOVA $^{\text {a }}$} \\
\hline Model & \multicolumn{1}{c}{ Sum of Squares } & df & Mean Square & \multicolumn{1}{c}{ F } & Sig. \\
\hline 1 & Regression & 1224829612,783 & 3 & 408276537,59 & 51,809 &, $000^{\mathrm{b}}$ \\
& & 323098440,017 & 41 & 7880449,757 & & \\
& Residual & 328052,800 & 44 & & & \\
Total & 1547928052,0
\end{tabular}

a. Dependent Variable: Harga Saham

b. Predictors: (Constant), Financial Leverage, EPS, DPS

Sumber: Pengolahan SPSS (2019)

Dari tabel 4.9 di atas, pengujian ini secara simultan (bersama-sama) variabel $E P S, D P S$ dan Financial Leverage diperoleh $\mathrm{F}_{\text {hitung }}$ 1,45 dengan menggunakan tingkat kepercayaan $95 \%$ $\alpha=5 \%$ df 1 (jumlah variabel atau 4-1=3 dan df $2(n-k-1)$ atau 45-3-1 = 41 (n jumlah data variabel independen). Hasil pengujian statistik, diperoleh nilai $\mathrm{F}$ hitung 51,809 dengan nilai probabilitas signifikan 0,000. Nilai $\mathrm{F}_{\text {hitung }} 51,809>\mathrm{F}$ tabel 1,45 dan nilai probabilitas Sig. 0,000 $<0,05$. Sehingga Ho ditolak dan Ha diterima, berarti bersama-sama (simultan) variabel EPS, DPS dan Financial Leverage berpengaruh signifikan terhadap harga saham.

\section{Pembahasan}

\section{Pengaruh EPS terhadap Harga Saham}

Hasil pengujian Hipotesis (H1) ditetapkan terdapat pengaruh positif dan signifikan antara variabel EPS terhadap harga saham. Hal ini dapat dibuktikan dengan nilai $t_{\text {hitung }} 11,464>$ $\mathrm{t}_{\text {tabel }} 2,0555$ dan nilai signifikansi sebesar $0,000<0,05$. Maka hipotesis penelitian menyatakan bahwa EPS berpengaruh positif dan signifikan terhadap harga saham. Sehingga dapat disimpulkan $\mathrm{H} 1$ diterima.

Hasil penelitian ini didukung dengan penelitian yang dilakukan oleh (Manoppo, 2017) yang meneliti perusahaan Food and Beverages di BEI dengan jumlah sampel sebanyak 12 perusahaan dan menegaskan bahwa variabel EPS pengaruh signifikan terhadap harga saham.

\section{Pengaruh DPS terhadap Harga Saham}

Hasil pengujian hipotesis (H2) ditetapkan bahwa terdapat pengaruh positif dan signifikan antara variabel DPS terhadap harga saham. Hal ini tidak sesuai dengan nilai $t$ hitung $0,339<\mathrm{t}_{\text {tabel }} 2,0555$ dan nilai signifikansi sebesar $0,737>0,05$, sementara hipotesis penelitian menyatakan bahwa DPS berpengaruh positif dan signifikan terhadap harga saham. Sehingga dapat disimpulkan $\mathrm{H} 2$ ditolak.

Hasil penelitian ini tidak sesuai dengan penelitian yang dilakukan oleh (Egam, 2017) yang meneliti perusahaan LQ45 di BEI dan sampel penelitian 20 perusahaan bahwa DPS tidak memiliki pengaruh terhadap harga saham diperoleh nilai signifikan 0,793 lebih besar dari 0,05. Kemudian ditegaskan oleh penelitian yang dilakukan oleh (Arianto, 2018) yang meneliti 
perusahaan manufaktur di BEI dan sampel penelitian berjumlah 78 dan menyatakan bahwa DPS berpengaruh signifikan terhadap harga saham diperoleh nilai signifikan 0,024 lebih kecil dari 0,05 .

\section{Pengaruh Financial Leverage terhadap Harga Saham}

Hasil pengujian hipotesis (H3) ditetapkan terdapat pengaruh positif dan tidak signifikan antara variabel Financial Leverage terhadap harga saham. Hal ini ditegaskan dengan nilai $t$ hitung $1,619<\mathrm{t}$ tabel 2,0555 dan nilai signifikansi sebesar 0,113>0,05. Maka hipotesis penelitian menyatakan bahwa Financial Leverage berpengaruh positif dan tidak signifikan terhadap harga saham. Sehingga dapat disimpulkan H3 ditolak.

Hasil penelitian ini sesuai dengan penelitian yang dilakukan oleh (Fredy Sondakh, 2015) yang meneliti perusahaan LQ45 di BEI dan sampel penelitian 20 perusahaan bahwa DPS tidak memiliki pengaruh terhadap harga saham.

\section{Pengaruh EPS, DPS dan Financial Leverage terhadap Harga Saham}

Berdasarkan hasil uji F, nilai $F_{\text {hitung }} 51,809>\mathrm{F}$ tabel 2,91 dan nilai probabilitasnya Sig. 0,000 < 0,05. Sehingga Ho ditolak dan Ha diterima, jadi disimpulkan bahwa variabel EPS, DPS dan Financial Leverage secara bersama-sama berpengaruh signifikan terhadap harga saham.

\section{SIMPULAN}

Penelitian ini bertujuan untuk mengatahui pengaruh EPS, DPS dan Financial Leverage terhadap harga saham. Berdasarkan hasil analisis data dan pembahasan yang telah dilakukan dengan uji SPSS 22 maka dapat dismpulkan sebagai berikut:

1. Hipotesis penelitian yang pertama, EPS berpengaruh positif dan signifikan terhadap harga saham. Serta dilakukan pengujian hipotesis uji t diperoleh nilai signifikan 0,000 lebih kecil dari 0,05 . Hasil penelitian ini ditetapkan bahwa hipotesis pertama diterima karena EPS berpengaruh positif dan signifikan terhadap harga saham.

2. Hipotesis penelitian yang kedua, DPS berpengaruh positif dan signifikan terhadap harga saham. Serta dilakukan pengujian hipotesis uji t diperoleh nilai signifikan 0,737 lebih besar dari 0,05. Hasil penelitian ini menunjukkan bahwa hipotesis kedua ditolak karena $D P S$ berpengaruh positif dan tidak signifikan terhadap harga saham.

3. Hipotesis penelitian yang ketiga, Financial Levergae berpengaruh negatif dan signifikan terhadap harga saham. Serta dilakukan pengujian hipotesis uji t diperoleh nilai signifikan 0,113 lebih besar dari 0,05 . Hasil penelitian ini menunjukkan bahwa hipotesis ketiga ditolak karena Financial Leverage berpengaruh positif dan tidak signifikan terhadap harga saham.

4. Hipotesis penelitan yang keempat, EPS, DPS dan FinancialLeverage secara bersamasama berpengaruh signifikan terhadap harga saham. Hipotesis penelitian ini dapat dibuktikan dari uji F nilai signifikasi 0.000 lebih kecil dari 0,05. Hasil uji Adjusted $R$ square menunjukkan nalai sebesar 0,776 atau $77,6 \%$. Hal ini menunjukkan bahwa pengaruh variabel EPS, DPS dan Financial Leverage terhadap harga saham sebesar $77,6 \%$. Sedangkan sisanya $22,4 \%$ dipengaruhi oleh variabel lain yang tidak dimasukkan dalam penelitian ini

\section{DAFTAR PUSTAKA}

Arianto, F. (2018). Pengaruh Current Ratio, Return On Equity, dan Net Profit Margin terhadap Harga Saham pada Perusahaan Manafaktur yang terdaftar di Bursa Efek Indonesia tahun 2014-2016, 02(02).

darmadji. (2001). Beberapa sudut pandang untuk membedakan jenis-jenis saham.

Egam, G. E. Y. (2017). Pengaruh Return On Asset (ROA), Return On Equity (ROE), Net Profit Margin (NPM), dan Earning Per Share (EPS) terhadap Harga Saham Perusahaan yang tergabung dalam Indeks LQ45 di Bursa Efek Indonesia periode 2013-2015, 5(1), 105-114. Ghozali, I. (2013). Aplikasi Analisis Multivariate Dengan Program IBM SPSS 21 Update PLS 
Regresi (Edisi ketu). Semarang: Badan Penerbit Universitas Diponegoro.

Hadi, N. (2015). Pasar Modal (Edisi Kedu). Yogyakarta: Graha Ilmu.

Hariyani, I. (2010). Buku Pintar Hukum Bisnis Pasar Modal (cetakan pe). Jakarta: Visimedia.

Kasmir. (2012). Analisis Laporan Keuangan (Edisi 5). Jakarta: PT Raja Grafindo Persada.

Kasmir. (2015). Analisis Laporan Keuangan (Cetakan ke). Jakarta: PT RajaGrafindo Persada.

Manam, H. A. (2017). Aspek Hukum dalam Penyelenggaraan Investasi di Pasar Modal Syariah Indonesia (edisi kedu). Jakarta: Kencana.

Manoppo, V. C. O. (2017). Pengaruh Current Ratio, DER, ROA dan NPM terhadap Harga saham pada Perusahaan Food and Bevarages yang terdaftar di BEI periode 2013-2015, $5(2), 1813-1822$.

Mogonta, K. (2016). Analyzig the Effect Return On Assets, Return On Equity and Earning Per Share On Market Share Price: A Study Of LQ-45 Mining Companies Listed On Indonesia Stock Exchange, 4(2), 703-713.

Paskalis, F. P. (2016). Semakin Dekat Dengan Pasar Modal Indonesia (edisi pert). Yogyakarta: CV Budi Utama.

Prayatno, D. (2016). Belajar Alat Analisis Data dan Cara Pengolahan dengan SPSS (Cetakan I). Yogyakarta: Gava Media.

Priyatno, D. (2017). Panduan Praktis Olah Data Menggunakan SPSS. Yogyakarta: IKAPI.

Rohsikah. (2018). Effects of Return on Asset, Return On Equity, Earning Per Share on Corporate Value, 7(3), 6-14. https://doi.org/10.9790/1813-0703010614

Siamat. (2004a). ciri-ciri dari saham biasa.

Siamat. (2004b). ciri-ciri dari saham preferen.

Siregar, S. (2014). Statistik Parametrik Untuk Penelitian Kuantitatif. Jakarta: PT Bumi Aksara.

Soemitra, A. (2015). Bank dan Lembaga Keuangan. Jakarta: Prenadamedia Group.

Sondakh, F. (2015). Current Ratio, Debt to Equity, Return On Assets, Return On Equity, Pengaruhnya terhadap Harga Saham pada Indeks LQ 45 di BEI periode 2010-2014, 3(2), $749-756$.

Sugiyono. (2014). Metode Penelitian Kuantitatif, Kualitatif, dan R\&D (cetakan KE). Bandung: Cv. Alvabeta.

Sujarweni, W. (2015). Metodologi Penelitian Bisnis \& Ekonomi (Cetakan I). Yogyakarta: PustakaBaruPress.

Wibowo, A. E. (2012). Aplikasi Praktis SPSS dalam Penelitan (Cetakan I). Yogyakarta: Gava Media.

Yusril, M. (2017). ANALISIS PENGARUH EARNING PER SHARE, DIVIDEND PER SHARE, DAN FINANCIAL LEVERAGE TERHADAP HARGA SAHAM PERUSAHAAN MANUFAKTUR YANG TERDAFTAR DI BURSA EFEK INDONESIA PERIODE 2013-2016, 3(6), 67-72.

Zulfikar. (2016). Pengantar Pasar Modal dengan Pendekatan Statistika (cetakan I). Yogyakarta: CV Budi Utama. 